\title{
P15 - Atopy and acute urticaria in childhood: is there an association?
}

\author{
George N Konstantinou ${ }^{1,2^{*}}$, Stefania Totska ${ }^{2}$, Dimitra Georgiadou ${ }^{2}$, Maria Farini ${ }^{2}$, Alexandra Terzi ${ }^{2}$, \\ Despina Tsonoglou ${ }^{2}$, Rozalia Valeri ${ }^{2}$ \\ From 3rd Pediatric Allergy and Asthma Meeting (PAAM) \\ Athens, Greece. 17-19 October 2013
}

\section{Background and objective}

Acute urticaria (AU) is a common condition that often presents in childhood. In this questionnaire-based prospective study we aim to investigate if there is any association between $\mathrm{AU}$ and atopy.

\section{Methods}

Children up to 14 years of age presented with $\mathrm{AU}$ in the emergency department (ED) of a reference children's hospital in the area of Thessaloniki were prospectively recorded. ED pediatricians filled out a relevant questionnaire per patient in the context of the taken personal medical history. Records included any doctor-diagnosed allergic disease and information derived from questions based on the International Study of Asthma and Allergies in Childhood (ISAAC) to identify any current or past allergic disease. Demographics and AU characteristics were additionally recorded.

\section{Results}

256 AU cases (138 boys), 5.1 \pm 3.3 years old were recorded. Prevalence of AU did not differ with regards gender $(P=0.376)$. The most common potentially associated triggers were food consumption, infections, hymenoptera stings, and vaccination. Atopy was not found to influence AU prevalence $(P=0.156)$ or co-occurrence of angiooedema $(P=0.226)$ which presented in $35.7 \%$ of the AU patients. Moreover angiooedema occurred independently of gender $(P=0.085)$, with a trend to be more prominent in older children ages $(P=0.061)$ and frequently associated with hymenoptera stings $(P=0.001)$ but not be so frequent in the presence of an infection $(P=0.005)$.

\section{Conclusions}

Atopy does not appear to predispose to acute urticaria with or without angiooedema in children.

\section{Authors' details}

${ }^{1} 424$ General Military Training Hospital, Thessaloniki, Greece. ${ }^{2}$ First Pediatric Department, Aristotle University of Thessaloniki, Hippokration General

Hospital, Thessaloniki, Greece.

Published: 28 February 2014

\section{doi:10.1186/2045-7022-4-S1-P70}

Cite this article as: Konstantinou et al:: P15 - Atopy and acute urticaria in childhood: is there an association? Clinical and Translational Allergy 2014 4(Suppl 1):P70.

\section{Submit your next manuscript to BioMed Central and take full advantage of: \\ - Convenient online submission \\ - Thorough peer review \\ - No space constraints or color figure charges \\ - Immediate publication on acceptance \\ - Inclusion in PubMed, CAS, Scopus and Google Scholar \\ - Research which is freely available for redistribution \\ Submit your manuscript at www.biomedcentral.com/submit}

() Biomed Central

(C) 2014 Konstantinou et al; licensee BioMed Central Ltd. This is an Open Access article distributed under the terms of the Creative Commons Attribution License (http://creativecommons.org/licenses/by/2.0), which permits unrestricted use, distribution, and reproduction in any medium, provided the original work is properly cited. The Creative Commons Public Domain Dedication waiver (http://creativecommons.org/publicdomain/zero/1.0/) applies to the data made available in this article, unless otherwise stated. 